\title{
Integrated Reporting: The Changing Nature of Accounting Profession
}

\author{
Tishta Bachoo ${ }^{1}$ \\ ${ }^{1}$ School of Accounting, Curtin Mauritius, Mauritius \\ Correspondence: Tishta Bachoo, School of Accounting, Curtin Mauritius, Mauritius. E-mail: \\ tbachoo@curtinmauritius.ac.mu
}

Received: November 13, 2018

Accepted: December 10, 2018

Online Published: December 14, 2018

doi:10.5430/afr.v8n1p49

URL: https://doi.org/10.5430/afr.v8n1p49

\begin{abstract}
Integrated Reporting (IR) is a new concept which has been receiving considerable attention from the global community since the formation of the International Integrated Reporting Council (IIRC) in 2010. Mauritius is a fast developing country where IR has gained growing traction over the last three years. It is important to understand the potential for IR in this island where sustainable development must be central to economic thinking as the island state has to preserve its resources in the long run. The purpose of this paper to find out the organizational benefits and implementation challenges of preparing an Integrated Report in Mauritius. It is also extended to identify the knowledge and skills employers perceive relevant for future accounting graduates. A survey is carried out to extract responses from report preparers and other stakeholders (investors, analyst and auditors) from a wide range of industries in Mauritius, to explore their opinions regarding IR. Findings signify that IR is being adopted by a majority of companies in Mauritius, although it is a relatively new concept. A majority thinks IR is improving the current corporate reporting. However, the fear of divulging market and/ or price sensitive information is the main challenge facing the practices of IR in Mauritius. The findings may be useful to better understand the likely development of IR in developing markets, as most of the previous studies on IR focused on developed countries and South Africa.
\end{abstract}

Keywords: accounting, accounting profession, integrated reporting, technology, Mauritius

\section{Introduction}

The environment in which accountants work is rapidly changing due to the emergence of information technology and the globalization of economies (Tan \& Laswad, 2018). For years, businesses have been held back by markets focused on the short-term, a lack of long term thinking and a shortage of information on the true sources of reliable value creation in a company over time - things like innovation, brand equity, customer loyalty, and key stakeholder relationships (IR Technology Initiative, 2016). Fortunately, there is a tool to help businesses understand, manage and communicate about the sources of value creation: IR.

As described by the IIRC, IR is an evolution of corporate reporting, emphasizing on conciseness, strategic relevance and future orientation (IIRC, 2013). IR is gaining momentum globally and it has the potential to bring about transformational changes in the roles of accounting professionals and in the standing of the profession itself. This sort of next-generation approach to business thinking, management and reporting depends on broader information sets and quicker, more sophisticated ways of analyzing the material information required for decision-making (IR Technology Initiative, 2016).

IR has evolved rapidly since the International Integrated Reporting Council (IIRC) was founded in 2010 (Hopwood, Unerman \& Fries, 2010). In 2015, the IIRC's then CEO, Paul Druckman, used a journey metaphor to explain developments in IR practice: "IR is a journey and it will take more than one reporting cycle to get there. As businesses start to use IR as a tool to better understand the connections between key resources and relationships that contribute to their success, and as a result make more informed decisions, the real value of integrated thinking and the integrated report will be realized" (IIRC, 2015).

While the accounting role was restricted to the provision of financial information and analysis, in the current climate, more and more investors demand non-financial data when screening a company. Therefore, businesses are expected to report not just on profit but on their impact on the wider economy, society, and the environment. In this context, IR comes handy as it gives a 'dashboard' of an organization's activities and performance in this broader information flow. In modern companies, it requires the application of technology to the transition from the current model of 
management practice and corporate reporting (largely financial only) to an integrated view.

However, prior studies on IR in the African context are rare except for South Africa where a number of empirical studies exist (Ahmed Haji and Anifowose, 2016; Steyn, 2014; Atkins and Maroun, 2015; Setia, Abhayawansa, Joshi, \& Huynh, 2015; Ahmed Haji and Anifowose, 2017; Ahmed Haji and Hossain, 2016, McNally, Cerbone, \& Maroun 2017). Little in other developing countries such as Islam and Islam (2018) (Bangladesh) and Lipunga (2015) (Malawi). The mainstream of empirical studies have utilized evidence from UK, US, Europe and Asia. Internationally, there is still limited research on IR (Adhariani and de Villiers, 2018; Lodhia, 2015; Haller and Van Staden, 2014; Robertson and Samy, 2015; Atkins, Solomon, Norton \& Joseph, 2015). Thus, this study fills the gap in literature by exploring the organizational benefits and implementation challenges of preparing an IR in Mauritius as an African country. It is mainly trying to answer the following questions, from accounting employers' perspectives: RQ1: To what extent companies in Mauritius are adopting IR? RQ2: What are the perceived benefits and challenges for report preparers? RQ3: Which ICT tools and techniques are they currently using in the implementation and preparation of IR? RQ4: What are the relevant ICT skills needed by Mauritian accountants in the field of IR?

To achieve its aims, the paper proceeds as follows: Section 2 provides an overview of IR's literature. Section 3 explains the methods used to capture data for further analysis. Section 4 presents results and is dedicated to a discussion of the findings. The final section draws conclusions and sketched an agenda for future research.

\section{Literature Review}

Prior to the adoption of IR, stakeholders were either interested in financial data or in Environmental, Social and Governance (ESG) data, but rarely both. The company's integrated report attempts to show the interdependency of non-financial and financial performance (Eccles and Saltzman, 2011). Moreover, there is now a growing adoption of already established frameworks and guidelines that serve to assist companies in their journey towards issuing the integrated report (Petrova, 2015). Some of these include the International Integrated Reporting Framework and the Global Reporting Initiative (GRI) - allegedly the most widely adopted guidelines on reporting non-financial information (GRI, 2018).

The International Integrated Reporting Council (IIRC) (2013) defines IR as "a process founded on integrated thinking that results in a periodic integrated report by an organization about value creation over time and related communications regarding aspects of value creation". Therefore, preparing a single integrated report, also referred to as 'One Report', eliminates the ambiguity of disclosing both financial and non-financial information in a clear and concise manner (Owen, 2013; Eccles, 2010). IR adds value to a company by highlighting how green and ethical values drive long-term growth (Nylander, 2015).

Mr. Richard Howitt, current CEO of IIRC stated in his interview on 22 May 2017 that, over 1,500 global businesses from big companies like PepsiCo and Unilever to major banks like Deutsche Bank and big major pharmaceutical companies as well as insurance companies, have adopted IR principles for various reasons (EY, 2017). While some have adopted IR because of legislative pressure (for example in South Africa and Brazil where IR is mandatory by law), others have understood the benefits derived from it, in the form of reputation, effective decisions and capital allocation, profit increases on short and long-term, future orientation, stakeholder agreement, retaining customers and employees (Roman, 2017). Research provides evidence of momentum towards IR in other countries, including the United Kingdom, the Netherlands, Australia, Spain, Singapore, Japan and the United States of America. Whether applied on a voluntary basis or not, IR practices provide many advantages such as reputation, a better understanding of the impact of the business on the environment or society or correlating financial and non-financial performances (Bhasin, 2017). However, Islam and Islam (2018) sated that companies in Bangladesh still lack in providing an integrated report connecting financial and non-financial information.

Adoption of IR results in several improvements that are indirectly linked to performance, like relations with external stakeholders, improvement in decision making and management of information, improving what is measured and connecting departments. According to Reimsbach, Hahn and Gürtürk (2017), an integrated report might influence the valuation of a company and in the end, attract more investors. However, the implementation of IR is not without its challenges. There will be need for the co-ordination of inter-functional activities (Eccles \& Saltzman, 2011) because an integrated report calls for the synchronization of financial and non-financial information to be elicited across various departments in an organization. Technology plays an important role in IR adoption. Software would have to be acquired to fuse financial and non-financial data. Information Technology hardware may also have to be procured to capture relevant tangible and non-tangible data. Investment would have to be made to train human assets of organizations on IR. Since the IR framework is still evolving, organizations will have to decide on the appropriate level of details to disclose. At the heart of these barriers to implementation is cost. The acquisition of computer 
equipment, training of staffs, and awareness creation all call for financial commitment.

Finally, Although a similar research has been conducted in developing countries such as Bangladesh (Islam and Islam, 2018), Malawi (Lipunga, 2015), and Indonesia (Adhariani and de Villiers, 2018), results cannot be expected to be the same in Mauritius due to significant contextual differences in terms of corporate reporting, the use of corporate information and the corporate culture.

\subsection{The Research Framework}

The aim of this study is to determine relevant knowledge and skills required of accounting graduates in Mauritius, taking into consideration the digital era and the new emergence in reporting. This study uses human capital theory, stakeholder theory and employability skills research, as key components supporting the development of the workforce to meet the demands of employers in the 21 st century. The human capital theory states that education is the most important component of human capital development (Becker, 1993). Not only are employers demanding an educated workforce (Robert Half, 2016), but they are also demanding employees to have relevant skills (Schurman \& Soares, 2010). Freeman (1984) defines stakeholders as "any group or individual who can affect or is affected by the achievement of the organization's objectives". One way of learning how universities work, requires the knowledge of stakeholders (Avci, Ring \& Mitchelli, 2015). Knowing who stakeholders are and the reasons they are stakeholders can greatly assist higher education administrators in understanding and operating their job and the institution. Benneworth and Jongbloed (2010) suggest that the stakeholder groups of universities would include the government, administration (vice-chancellor, senior administrators and top management), academics, clienteles (students, employers), suppliers, competitors, donors, communities, non-governmental regulators, financial intermediaries and joint-venture partners. Stakeholder theory suggests that the success of an organization depends on its ability to balance the conflicting needs of its various stakeholders (Dellaportas et al. 2005). One of the indicators of success for an organization would, therefore, be how well the needs of its stakeholders are met. Among the various stakeholder groups identified in Benneworth and Jongbloed (2010) and Chapleo and Simms (2010), students/graduates, employers and higher education institutions' (HEIs') staff (top management, administration and academics) are the stakeholder groups that are closest to the workplace. However, for this research, focus is given to employers because they are at the heart of the objectives of this research. Employers require from graduates of higher education institutions to have abilities and skills that coincide with those required by their organizations (Nicolescu \& Paun, 2009). Since the study determines the knowledge and skills which are considered relevant to accounting employers, those who educate the accountants should provide the requisite education. The theories used are illustrated in the conceptual framework below.

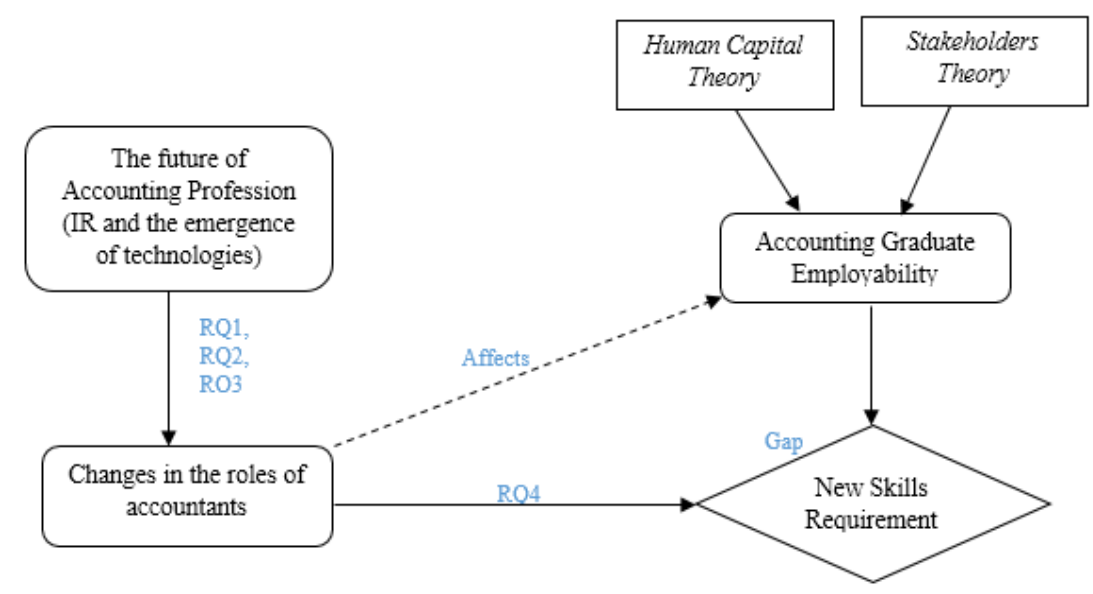

Figure 1. Conceptual Framework

\section{Method}

To answer the research questions developed in the previous section, a survey instrument is used targeting corporate report preparers and other stakeholders (investors, analyst and auditors). The survey which was adapted from the Malaysian Institute of Accountants (MIA) - ACCA (2016) and the Institute of Singapore Chartered Accountants (ISCA) - National University of Singapore (NUS) (2014) IR surveys, allowed numerous forms of questions to be asked and enabling proper feedback. The survey was directed in a specific way in order to invite and receive as many responses. In this research, both primary and secondary data were collected. As a result of a dearth of Mauritian 
studies relevant to IR, studies from foreign countries were used to meet the targeted objectives of this research. In this research, the population encompasses the accounting practitioners from a wide range of industries. The first target was the 13 companies which have won the SEM Sustainability Index (SEMSI) award (Stock Exchange of Mauritius [SEM], 2018). The reason these companies were chosen for this research is that they are already actively pursuing sustainability initiatives, while also facilitating responsible investment. However, due to a small population size, the data collection was extended to other listed companies and some multinational companies based in Mauritius, considering that these companies must have already adopted IR as this concept is no more new on the international level. The corporate report preparers were surveyed so as to get an idea of what they are doing in regards to the IR concept, and also how this new concept is changing their roles and that of their accounting staff members.

The total population sampling which is a type of purposive sampling technique that involves examining the entire population has been used (Etikan, Musa \& Alkassim, 2016). Due to the very small sample size and the uncommon characteristics of populations that make up a total population sample, the study looks at the samples in-depth using mixed research methods. To minimize non- response bias, the following steps were taken: (1) the participants were asked to complete the survey even if they had little or no interest in IR or if their companies have not implemented the concept; (2) online questionnaires were used to improve response rate and to allow the respondents to fill the surveys at their own time; and (3) the anonymity of the survey data was ensured.

Thus, out of the $\mathbf{1 0 0}$ companies which participated, $\mathbf{7 0}$ of them responded to the surveys. The respondents had to classify themselves into different groups based on the position they held:

(1) IR Preparer I: Audit Committee, Independent Directors and Board Members (4 coded as B01 to B04); (2) IR Preparer II: Chief Executive Officers; (3) IR Preparer III: Finance function including Chief Financial Officers, Financial Controllers and Accountants (39 and they were coded as P01 to P39); (4) IR Preparer IV: Corporate Communication, Sustainability Practitioner; (5) Auditors and Consultants (11 were consultants while 10 were auditors working in the companies, coded as C01 to C11 and A01 to A10, respectively); and (6) Other Stakeholders: Analysts and Shareholders (6 coded as S01 to S06) (Figure 2). Unfortunately, no IR preparers II (Chief Executive Officers) and IV (Sustainability Practitioner) filled in the survey so their views could not be analyzed. However, from the types of respondents who filled in the survey, it can be deduced that they were all from the accountancy field which implies that they were the right candidates who have knowledge about IR.

To calculate the descriptive values of the data, the software SPSS 22.0 is used. In return, we shall know the opinions of the respondents on different aspects of IR. The results are displayed on frequency table, bar chart and pie charts. The last two questions from the survey are open-ended questions which will be analyzed qualitatively.

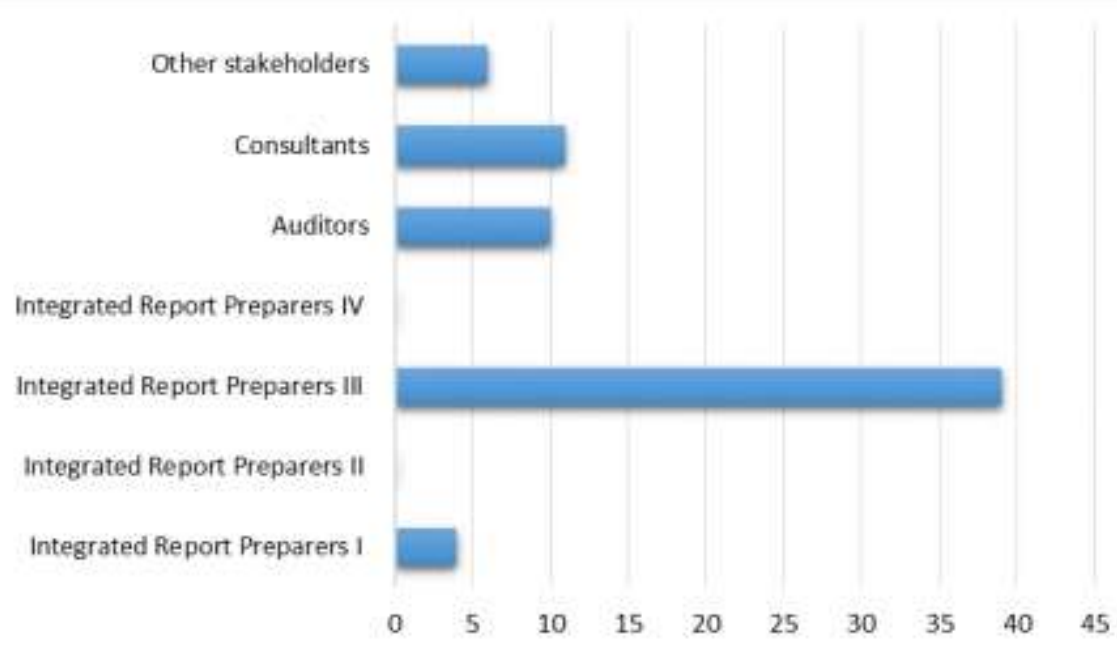

Figure 2. Categories of Reporting Stakeholders

The respondents were from a wide range of industry which has been classified in Figure 3. It can be deduced that the majority of the respondents were accounting practitioners from the financial sector and second was the manufacturing sector. 


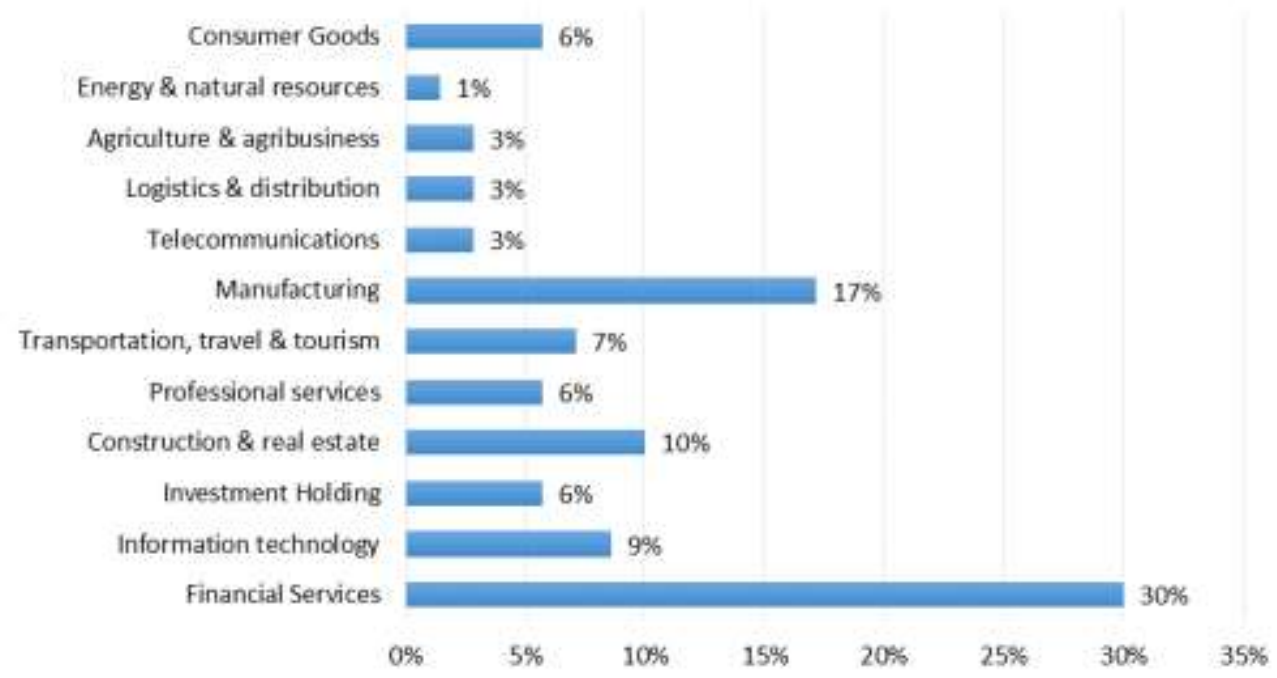

\section{Results and Discussion}

Figure 3. Companies from different industries

\subsection{Descriptive Analysis}

\subsubsection{IR Awareness}

The first question in section B of the survey was about the participants' IR awareness. They were asked to rate their awareness on a scale on 1 to 5,1 being 'no knowledge' to 5 being 'high knowledge'. Out of the 70 respondents, 11 and 22 of them gave a rating of 5 and 4 respectively (47\%) which are the top two knowledge categories, categorizing themselves as having higher than average level of knowledge in IR. $28(40 \%)$ of them gave a rating of 3 which was average knowledge. The remaining $9(13 \%)$ had little knowledge to no knowledge of IR. As it can be deduced, although IR is a relatively young initiative globally, and take-up by companies in Mauritius has so far been limited, these companies are not clueless about the concept. The majority of the respondents have more than just the basic notion of IR.

Table 1. Level of awareness

\begin{tabular}{lc}
\hline Level of awareness/ knowledge of IR & \% \\
\hline In depth or good knowledge (score of 5 - 4) & $47 \%$ \\
Average knowledge (score of 3) & $40 \%$ \\
Little to no knowledge (score 2 - 1) & $13 \%$ \\
\hline
\end{tabular}

Compared to the Malaysian survey, MIA-ACCA (2016) in which 13\% of the respondents had good or in depth knowledge, the situation in Mauritius was much better at 47\%. Similar to the MIA- ACCA (2016) and the Indonesian survey (Adhariani and de Villiers, 2018), the low level of knowledge in the Mauritian sample is understandable, given that IR is a new global initiative and the take up by companies has been limited. This implies that there may be a need to provide IR training (Adhariani and de Villiers, 2018) and this is further discussed in this study.

\subsubsection{IR Adoption in Mauritius}

The 70 companies were chosen to participate in the survey because, they deemed to be more inclined towards the sustainability aspect of business. Therefore, the researcher assumed that these would be the companies which have already adopted IR or are actively pursuing the adoption of IR. From the results, it can be analyzed that out of the 70 companies, 44 companies have already adopted IR while 26 are considering to adopt it in the near future. It can be deduced that none of the respondents answered 'No' which implies that they are positive about the adoption of IR. Later in the study, the factors which influence the adoption of IR in Mauritius will be discussed through a regression analysis. 


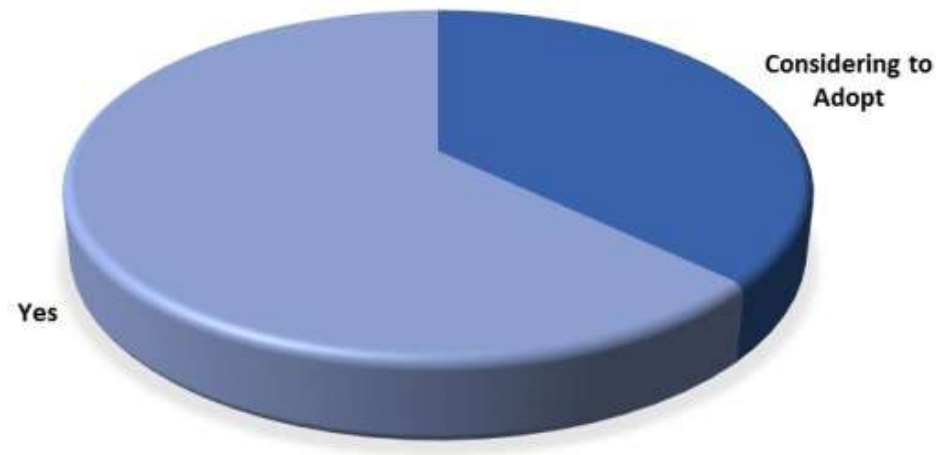

Figure 4. Adoption of IR in Mauritius

\subsubsection{Implementation Approaches of IR in Mauritius}

The preparers were also asked to share their opinion about how they think IR should be implemented in Mauritius. According to literature, different countries have different methods and regulations to implement IR. For example, in South Africa it is mandatory by law. Currently in Mauritius, it is important to note that adoption of IR is entirely on a voluntary basis. The decision is driven by the benefits to the company's own internal management and performance, and benefits that are expected to accrue to users of the reports.

However, to enhance corporate governance and the value creation in an integrated and coherent way, the majority of the survey respondents think that, IR is to be implemented in other Mauritian companies by regulation in some form. Yet, there is disagreement over the nature of the preferred regulatory approach. The largest group overall (44\%) think IR should be required on an 'apply or explain' basis, whereas $29 \%$ think IR should simply be made mandatory. According to King III Report on apply or explain approach, under this code, entities are given a set of standards to follow, but they're not mandated to comply with everything. They can choose which principles apply to them; however, they are expected to explain and be able to justify the reasons behind their choices.

Just under a third (27\%) of respondents think the introduction of IR in Mauritius should be market driven. Whatever the implementation approach, some participants think that the concepts underlying IR will be equally applicable to small and medium-sized enterprises (SMEs), the public sector and the not-for-profit organizations.

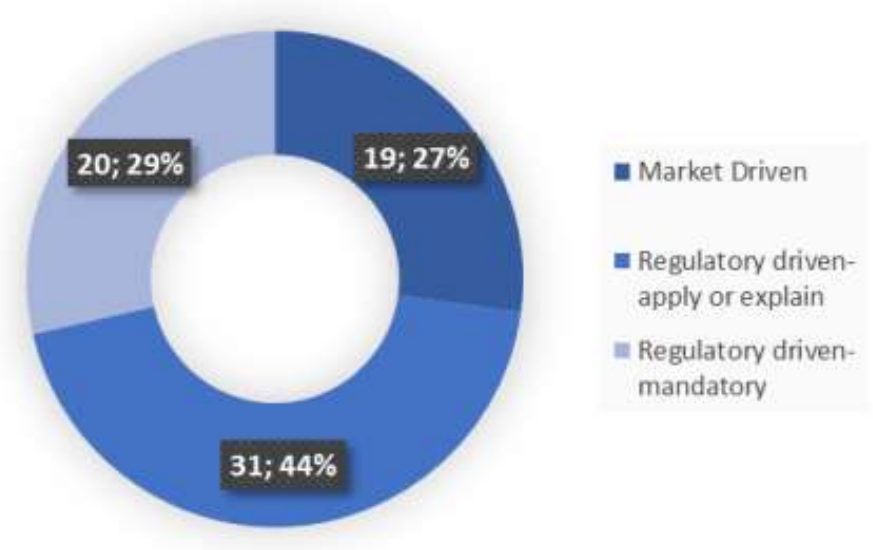

Figure 5. IR implementation approaches

More than $80 \%$ of the respondent believed that the widespread use of IR in Mauritius would make it more attractive location to conduct business and Mauritius would attract more investors. $16 \%$ were unsure but did not disagree with this idea. The positive findings in the present study were higher than those in the MIA-ACCA (2016) survey (54\%) and that of the Indonesian survey (66\%) (Adhariani and de Villiers, 2018). Nevertheless, no conclusion can be 
inferred from this statistics as it is important to note that that each of these countries are different in every aspect and so is the sample size being used currently.

RQ2: What are the perceived benefits and challenges for report preparers?

\subsubsection{Benefits in Adopting IR}

The report preparers have mentioned that IR in their companies is beneficial to their roles and that of their subordinates. Of this group, a majority (55 out of 70 respondents) thinks IR is improving the current corporate reporting. 15 of them answered "maybe" which means they are not very sure. This is because, these 15 have not yet implemented the concept.

This group was also asked to identify perceived benefits from a list, selecting as many as they liked. The dominant benefits they perceive included improving transparency and governance, improving communication with external stakeholders and promoting integrated thinking, all of which were in line with the MIA-ACCA (2016) survey. This finding is consistent with previous studies (Deegan and Rankin, 1997; and García-Sánchez, Rodríguez-Ariza and Frías-Aceituno, 2013)

Of lesser importance were the benefits related to easier access to capital, increased share price and improving efficiency. The findings suggest that the information provided in IR may be of little use for capital market participants, which is consistent with the findings of Rensburg and Botha (2014) in South Africa, and Hsiao and Kelly (2018) in Taiwan.

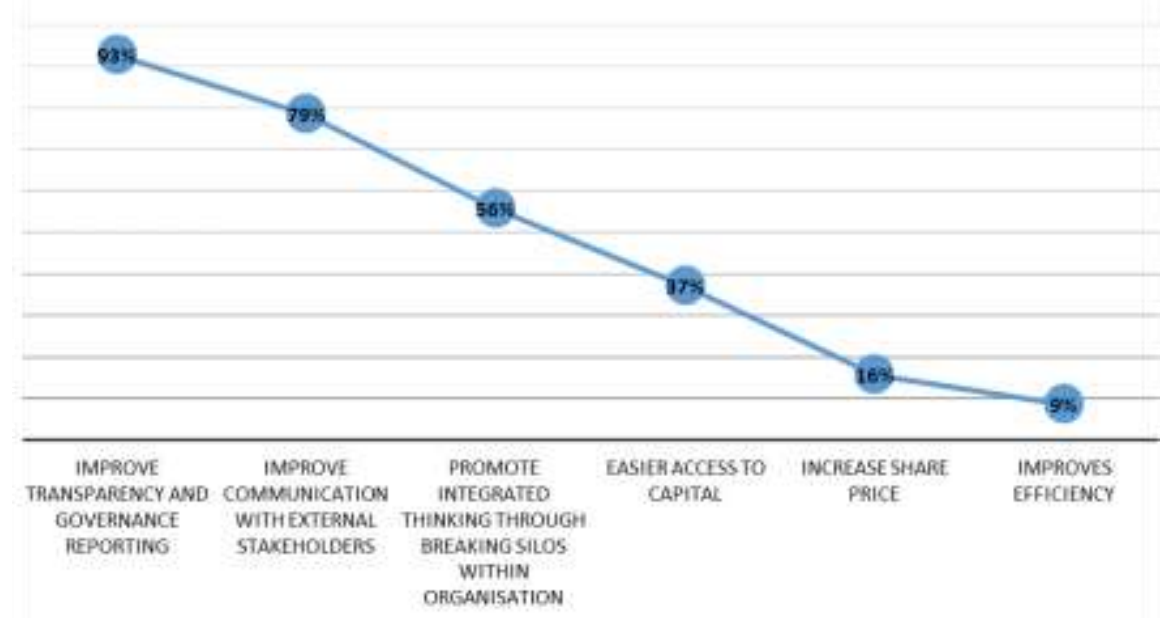

Figure 6. Perceived benefits in adopting IR

From the MIA- ACCA and the ISCA-NUS surveys, however, some participants expressed concerns about the fear of divulging market and/or price sensitive information and the costs associated with IR. Apart from these two concerns, the range of challenges anticipated when implementing, and some of the resources available to help address them, are considered in the next section.

\subsubsection{Challenges in Adopting IR}

All survey participants were asked what they see as the three main challenges in adopting. However, only the responses from the knowledgeable respondents ( 3 or above a five- point scale) have been analyzed to avoid biasness. Emerging at the top of the list is the fear of divulging market and/ or price sensitive information (56\%). Compared to other surveys conducted where this challenge was not the main one, for this research however, participants have acknowledged that IR would provide more balance reporting to all stakeholders but they have the fear of not being able to balance the information disclosed, especially when it comes to sensitive information. As indicated by du Toit, Van Zyl and Schutte (2017), significant uncertainty will remain regarding the amount of disclosure required, even among South African companies which are the pioneer of IR.

The second-ranked perceived challenge is the lack of proper information system to produce the IR (49\%). Dumay, Bernardi, Guthrie \& Demartini (2017) similarly report inadequate information systems as a barrier to IR implementation. This can be explained by the broad range of information required by stakeholders today, implying that companies need to cover the information in up to date systems so that reliable reports can be generated. It is also 
important to note that IR is a new concept, therefore, it might take some time to evolve a company's information systems to support the shift to integrated thinking. It cannot happen overnight.

The third-ranked challenge perceived by $41 \%$ of the respondents is the cost of preparation. Some respondents clearly doubt whether the benefits of IR would outweigh the costs. They also believe adoption of IR may further increase the cost of doing business.

The lack of guidance on how to prepare an integrated report is also a key challenge in the eyes of $36 \%$ of the respondents. This concern comes through strongly in responses to later survey questions asking about the support participants would like when adopting IR, where use of technological tools and training are common requests.

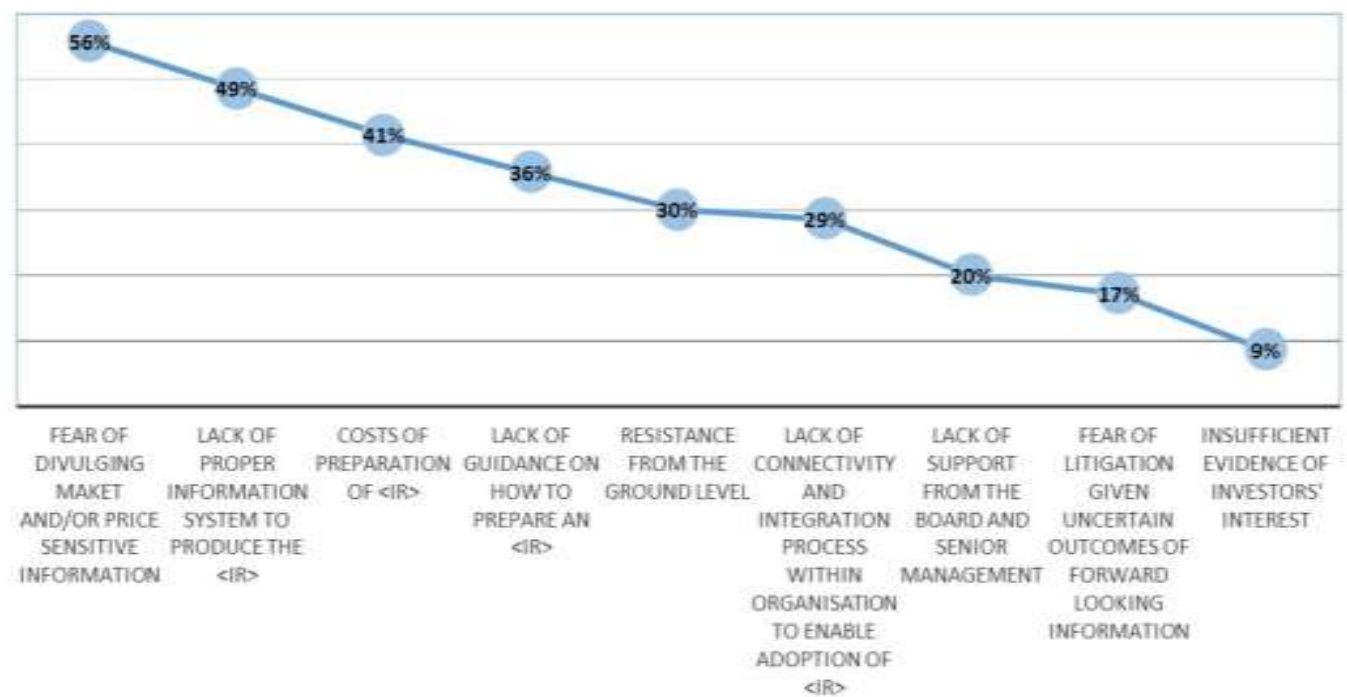

Figure 7. Perceived challenges in adopting IR

From previous research, it can be concluded that survey participants were least concerned about the risk of ground level resistance to within organizations. However, in this survey, this concern is substantial (identified by $30 \%$ of respondents). This may be because IR is a new concept and it is taking off gradually. Therefore, preparers of IR would have some reluctance if they are not given the appropriate training or ample time to grasp the concept well.

Similarly, the lack of connectivity and integration process within organizations to enable adoption of IR is a substantial challenge (identified by $29 \%$ ). This can be mitigated by having a content guideline for each section of the annual report and an overall reviewer on contents help to overcome this challenge. Lack of support from the board and senior management is a challenge identified by $20 \%$ of respondents. Even if this challenge is not highly substantial, board commitment and backing is vital for any major initiative within an organization, and IR is no exception.

Almost $17 \%$ of respondents see a hurdle arising from fear of litigation given the uncertain outcomes of forward-looking information that might be included in an IR. It should be clarified that the International IR Framework is principle-based and does not prescribe the specific content. Companies need to use their judgment to determine what is considered material information that should be included to give readers a better understanding of their value creation potential.

Survey participants are least concerned about insufficient evident of investor's interest, which is identified as a challenge by only $7 \%$. This suggests, investors appear to be recognizing that IR is designed to give them a more complete picture of a company's ability to create value over the short, medium and long term. This can also be backed the high number of positive responses when participants were asked if they believe that if IR is commonly used by companies in Mauritius, will they make the economy more attractive to investors. While many respondents do see value for Mauritian businesses in adopting IR, noting its potential to increase transparency and provide investors with useful information, they also consider it a 'magic bullet' that will automatically attract investors.

Tackling these challenges is not easy or straightforward, but an increasing range of resources is available to corporate reporters and their advisers to help them implement and prepare IR successfully. An important first step to take to tackle the challenges discussed above, is to achieve board level and company-wide buy in for IR. This requires 
discussion and analysis of the relative costs and benefits of IR adoption. The IIRC has produced a series of documents intended to highlight how IR creates value to different groups, such as company boards and investors (IIRC, 2013). Besides, if proper training and educational activities are provided for companies to prepare for IR adoption, these challenges could be mitigated. Several previous studies explore perception on IR in different countries from the perspective of different stakeholders. Perego, Kennedy \& Whiteman (2016) suggested that IR is perceived as a diverse field, where progress is being made despite challenges.

The findings of this study so far indicate that there has been strong interest in IR in Mauritius, but it is equally important to gather respondents' perception about training, support and relevant tools and technologies so that companies can effectively implement and make use of this approach.

\subsection{Regression Analysis}

\subsubsection{Factors Influencing the Adoption of IR in Mauritius}

From the survey it could be deduced that 44 out of 70 respondents have adopted IR and the remaining are considering to adopt it (Figure 4). One of the factors which influence its adoption is the implementation. For instance, if IR is mandatory by law, companies have to adopt it. Other than the implementation approach, there are some other factors which influence the adoption of IR. Several variables were transformed into different themes on SPSS to ease analysis.

A regression analysis was then conducted to verify the relationship between the dependent variable and the independent variables. The dependent variable is the adoption of IR and the independent variables are those which influence its adoption, such as awareness of the concept, the cost for implementation, how beneficial it is to the roles of accountants, how relevant and significant it is to the accounting profession and lastly the value IR adds to the organization and shareholders. A multiple linear regression test was chosen to analyze the relationship between the dependent variable and independent variables in the sample. The rest showed the following results.

Table 2. Regression model summary

\begin{tabular}{cccccccccc}
\hline & & \multicolumn{1}{c}{ Change Statistics } \\
Model & $\mathrm{R}$ & R Square & $\begin{array}{c}\text { Adjusted R } \\
\text { Square }\end{array}$ & $\begin{array}{c}\text { Std. Error of } \\
\text { the Estimate }\end{array}$ & $\begin{array}{c}\text { R Square } \\
\text { Change }\end{array}$ & F Change & df1 & df2 & Sig. F Change \\
\hline 1 & $.492^{\mathrm{a}}$ & .242 & .183 & .880 & .242 & 4.097 & 5 & 64 & .003 \\
\hline
\end{tabular}

a. Predictors: (Constant), Aware, RelevanceSignificance, Cost, Beneficial, Addvalue

The model summary table shows an $\mathrm{R}$ value of 0.492 , an $\mathrm{R}$ square value of 0.242 and an adjusted $\mathrm{r}$ square value of 0.183 . The $\mathrm{R}$ square value is key for a factor analysis since it quantifies the percentage change in dependent variable which is caused the independent variables namely relevance and significance of IR, awareness, cost, benefits of IR and the value added. In a study done by Lehmann (1975), it was found that for most researches and studies, the value of R squared lied between 0.10-0.50 which is in line with the results obtained for this study. It can be concluded that $24.2 \%$ of the variance in the dependent variable adoption of IR can be explained by the independent variables. The same value suggests that $75.8 \%$ of the variance in the dependent variable is explained by other independent variables which have not been considered in this study.

The following table is the ANOVA table. This table shows the mean square, the F value, the significance level and the degree of freedom.

Table 3. ANOVA

\begin{tabular}{llccccc}
\hline & Model & Sum of Squares & df & Mean Square & F & Sig. \\
\hline 1 & Regression & 15.850 & 5 & 3.170 & 4.097 & $.003^{\text {b }}$ \\
Residual & 49.522 & 64 & .774 & & \\
Total & 65.371 & 69 & & &
\end{tabular}

a. Dependent Variable: Has your company adopted the IR concept?

b. Predictors: (Constant), Aware, RelevanceSignificance, Cost, Beneficial, Addvalue

The $\mathrm{F}$ value looks at the overall significance of a multiple regression analysis. To check whether the regression analysis is significant, the common practice is that the p-value should be less than 0.05 . Data from the table suggests that the $\mathrm{F}$ value is 4.097 while the $\mathrm{p}$-value is 0.003 . This implies that the regression analysis is significant and 
appropriate to determine the relationship between adoption of IR and the independent variables namely: awareness, relevance, cost, benefits of IR, and the value added.

To be able to generate a regression equation, the coefficients table was checked and the appropriate values were extracted.

\section{Coefficients $^{\mathrm{a}}$}

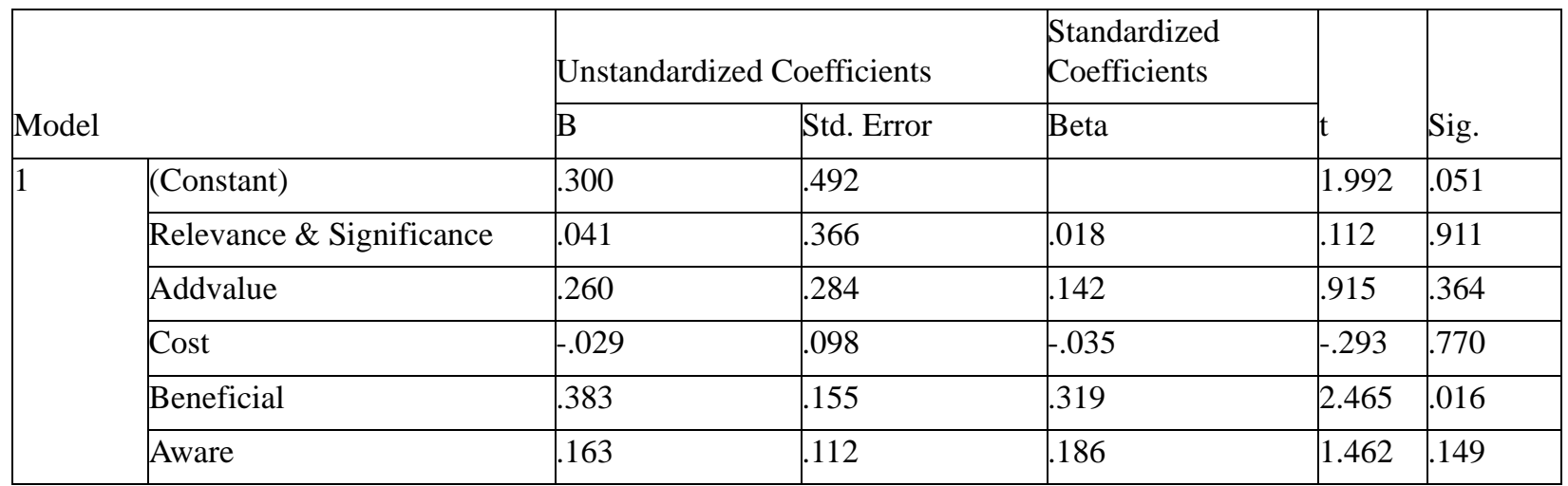

Dependent Variable: Has your company adopted the IR concept? ${ }_{\mathrm{a}}$

The coefficient table is the criteria as to whether to accept or reject factors. The significance level of 5\% was set and any p-value less than $5 \%$ was rejected. From the above table, the beneficial factor (0.016) is the only variable which has a p value between $0 \%$ and $5 \%$ and is therefore rejected. All independent variables except cost factor had a negative relationship with adoption of IR. The regression equation can be obtained from the coefficients table as follows:

$$
Y=0.300+0.41 \boldsymbol{X}_{\mathbf{1}}+0.260 \boldsymbol{X}_{\mathbf{2}}-0.029 \boldsymbol{X}_{\mathbf{3}}+0.383 \boldsymbol{X}_{\mathbf{4}}+0.163 \boldsymbol{X}_{\mathbf{5}}
$$

Where $\mathrm{Y}=$ Dependent variable, IR Adoption

$\mathrm{X} 1=$ Independent variable, Relevance

$\mathrm{X} 2=$ Independent variable, Add value

$\mathrm{X} 3=$ Independent variable, Cost

$\mathrm{X} 4=$ Independent variable, Beneficial

X5= Independent variable, Awareness

From this analysis, it can be highlighted that the factors which influence the adoption of IR is backed by the literature review.

\subsection{Factor Analysis}

RQ3: Which ICT tools and techniques are companies currently using in the implementation and preparation of IR?

To be able to answer this RQ about technological tools and techniques which form part of IR, the researcher needed to understand the perceptions of the respondents in regards to ICT in reporting. For this purpose, a list of likert scale statements under the themes developed in table 4, were added to the survey. Respondents had to choose from a scale of 5 (strongly agree, agree, neutral, disagree and strongly disagree) to share their views. Factor analysis has been used to test the sampling adequacy which will explain the importance of ICT in IR and how it is being used in the implementation and preparation of integrated reports. Table 4 displays a summary of the results obtained from the factor analysis. 
Table 4. Summary of factor analysis

\begin{tabular}{lcccc}
\hline $\begin{array}{l}\text { Themes based on group of } \\
\text { statements }\end{array}$ & $\begin{array}{c}\text { Kaiser-Meyer-Olkin } \\
\text { Measure }\end{array}$ & $\begin{array}{c}\text { Approx. } \\
\text { Chi-Square }\end{array}$ & $\begin{array}{c}\text { Mean on a scale } \\
\text { of 5 (Average) }\end{array}$ & $\begin{array}{c}\text { The Bartlett's Test of } \\
\text { Sphericity } \\
\text { (Significance) }\end{array}$ \\
\hline $\begin{array}{l}\text { Relevance of technology in } \\
\text { the accounting profession }\end{array}$ & 0.742 & 99.825 & 4.58 & .000 \\
$\begin{array}{l}\text { Significance of technology } \\
\text { in reporting }\end{array}$ & 0.696 & 162.051 & 4.35 & .000 \\
$\begin{array}{l}\text { Real time data in reporting } \\
\text { is due to technology }\end{array}$ & 0.577 & 16.296 & 4.09 & .001 \\
$\begin{array}{l}\text { Technology adds value to IR } \\
\text { and its users }\end{array}$ & 0.668 & 122.665 & 4.28 & .000 \\
\hline
\end{tabular}

Under each theme, several questions were asked to capture the perceptions of respondents in relation to the role of technology in IR. The Kaiser-Meyer-Olkin (KMO) test was done to check for the sample adequacy. Kaiser (1974) recommends to have a value greater than 0.5 for a satisfactory factor analysis to proceed. Looking at the table, the KMO measure for each factor is within 0.5 and 0.8 , which falls within the acceptable range. This suggests that factors are reliable and the sample is adequate for factor analysis.

Bartlett's test of Sphericity can be found on the same table. This is a statistical test for the presence of correlations among factors, providing the statistical probability that the correlation matrix has significant correlations among at least some of factors. For factor analysis to work some relationships between factors are needed. Thus, a significant Bartlett's test of sphericity is required, say $p<.005$. In this case the Bartlett's Test of Sphericity is significant at .000 and .001. Therefore, the Factor Analysis is valid. The significance level is small enough which means that the sample intercorrelation matrix did not come from a population in which the intercorrelation matrix is an identity matrix.

The next output from the analysis is the mean. The mean for each statement was calculated and then an average mean was calculated for each theme (group of questions). Most of the respondents agreed to all of the statements as the means calculated are above 4 on a scale of 5 . The respondents have the same opinion of the provided statements, that is, they believed ICT is crucial in IR.

\subsubsection{Types of IR Technology Being Implemented and Used}

The findings also revealed the types of ICT tools and techniques (system/ software) which are being used or will be used in the near future by companies in Mauritius to fulfill the requirements of IR. Table 5 below shows some of the reporting software that are being used by the companies surveyed. For instance XBRL, Oracle, SAS Business Intelligence and Cognus Reporting are the most used IR software by companies in Mauritius. Many companies which have recently adopted the concept, have got their report preparers to assist in the transition of reporting. Therefore, some of the respondents have got the opportunity to test the new reporting technologies while the Information Technology (IT) people were setting up the new system. The respondents mentioned that it is not easy to learn these technologies in the first place. They were required to carry out many tests to have the software running smoothly. For the testing, they were required to input past annual report data to check for system reliability.

Although some companies have not yet implemented the IR concept, yet respondents knew about the system/software they intend to use in the future as their companies are already considering the implementation. Therefore, they already know their service provider and which technology will be used. Some of the respondents mentioned that their companies will still use to same technology with a few add ons. 
Table 5. Types of IR technology in different companies

\begin{tabular}{|c|c|c|c|c|c|}
\hline A.01 & Koala & $\mathrm{ClO}$ & XCBRI. & 922 & Navision Software \\
\hline $\mathrm{A} 02$ & Sage & $\mathrm{C} 11$ & Crystal reports & $P 23$ & DA1S technology \\
\hline A.03 & Pastel & Po1 & DMS Accounting software & P24 & Heskaview Integrated reporting \\
\hline $\mathrm{A}, 04$ & Carriots Analytics & $\mathrm{P} 02$ & Odoo & P25 & Inets oft Technology \\
\hline A.05 & Caseware & P03 & SAS Business Intelligence & P26 & SAP \\
\hline A.06 & Navison & P04 & Oracle & $\$ 27$ & Quickbooks \\
\hline$A 07$ & SAP & Pos & XBRI. & $P 23$ & Cognus Reporting \\
\hline AOS & Cognus Reporting & POS & Sicorax Accounting & P29 & CPM Solutions \\
\hline$A .09$ & Panacea & P07 & XCBRI. & P30 & SAP \\
\hline A.10 & CRM and nisk anvlysis tool & POS & S.A.P & $P 31$ & Quaickbooks \\
\hline $\mathrm{B} 01$ & S.AS Business Intelligence & P09 & SAP Business one & P32 & Cognus Reporting \\
\hline $\mathrm{B02}$ & Slemma reporting & P10 & IBM Cogmus Business Intelligence & P33 & Quickbooks \\
\hline B03 & Bespoke soltwares & P11 & Phocas Software & P34 & Inetsof \\
\hline B04 & Oracle Business Intelligence & P12 & XI Reporting & P35 & S.AP \\
\hline $\mathrm{CO1}$ & A.PIs and Business Intelligence & P13 & S.AP Crystal Reports & P36 & XGRLL. \\
\hline $\mathrm{CO2}$ & CRMI \& Sharepoint & P14 & DMS Accounting software & P37 & XBPI \\
\hline$C 03$ & S.AS Business Intelligence & P15 & SAGE & P39 & Oracle \\
\hline $\mathrm{CO4}$ & APIs and Business Intelligence & P16 & Hyperion + Business intelligence solution & P39 & Bespoke softwares \\
\hline Cos & OBIFE (Oracle Business & P17 & NAN1 & S01 & Oracle \\
\hline 006 & MSicrosoft Word and S.AP & P18 & CEMITS & $\mathrm{S} 02$ & Oracle \\
\hline $\mathrm{CO}$ & XBRI. & P19 & Oracle based ERP & $\mathrm{S} 03$ & Cogntis Reporting \\
\hline $\cos$ & Quickbooks: & P20 & ProfitSword BI solution & S04 & XBPII \\
\hline CO9 & Macrosoft Dynamics NAV & $P 21$ & Oracle & sos & SAS Bus, Intelligence \\
\hline$\$ 06$ & Crystal Reponts & & & & \\
\hline
\end{tabular}

\subsection{Training of Employees}

The report preparers were asked if they were being given adequate training to cope with the IR concept and the relevant technologies. Out of the 70 respondents, 58 answered 'No' and 12 responded positively. This implies that many of the companies who responded to the survey agree that their employees are not trained at all to cope with the IR concept. Since this is taking a hype globally, it is very important for all accounting employees to have adequate knowledge and skills in IR.

Out of the 12 whose response were 'yes', 58\% mentioned that their employees were offered workplace training on IR. $25 \%$ got their training from professional qualification institutions, $8 \%$ sought training from service provider consultants. This group forms part of the companies which have recently implemented an IR software, therefore they obtained the training from the consultants/ software developers. Finally $8 \%$ of them obtained their training on IR as part of their degree in international universities. So, apart from training, conferences and seminars which have been recommended by Adhariani and de Villiers (2018), in the current study, it has been deduced that, HEIs in Mauritius are not providing adequate IR proficiency. Hence, it is very important for HEIs to respond to this lack of IR proficiency, including its technical aspects and its benefits.

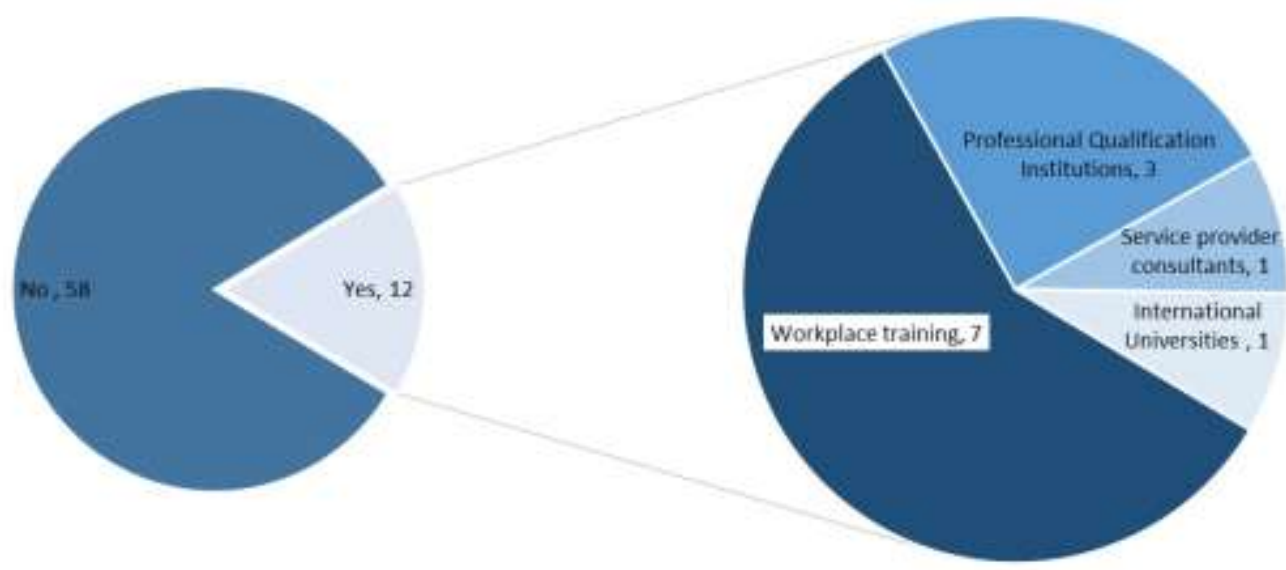

- Workploce training = Professional Qualification Institutions = Service provider consultants InternationalUniversities

Figure 8. Training of employees 
RQ4: What are the relevant skills needed by Mauritian accountants in the field of IR?

\subsection{Qualitative Analysis}

\subsubsection{Relevant Skills Perceived by Employers of Accounting Practitioners}

Following the question on the training of the employees, another question was asked to the employers about the knowledge and/or skills they deem relevant for the accounting practitioners to possess. With the emergence of ICT and the adoption of IR, the expectations of employers have changed compared to how they were some years back. This is because they have realized that the roles of accountants have changed. Therefore, the participants have argued upon skills and knowledge they look for when they hire accounting and finance people to work in their organization. From the 70 responses, some of the comments have been extracted for further analysis. Most participants mentioned ICT skills, reporting knowledge and skills as the most important and a minority considered generic skills as the most relevant one for future accountants to possess. The responses have been grouped according to different themes with the participants' comments quoted.

\subsubsection{ICT Literacy}

ICT skills are one of the fastest expanding skill sets today, and are currently in huge demand across multiple markets. More than just as an industry of its own, ICT has also permeated greatly into different job functions, evolving from being a specified niche to becoming a basic requirement across different verticals. 46 out of the 70 respondents have put much emphasis on the ICT skills which they perceive as necessary for accounting employees to have in order to be successful in their job. The following are quotes from some participants:

\begin{tabular}{|c|c|}
\hline $\begin{array}{l}\text { C02 } \\
\text { Financial } \\
\text { Services, } \\
\text { Consultant } \\
\text { 6-10 years }\end{array}$ & $\begin{array}{l}\text { They should be technologically savvy and be more flexible to move towards an ICT intensive work } \\
\text { environment. By default, they should have the basic knowledge of accounting software, oracle, } \\
\text { database, the Microsoft package. Moreover, it would be a plus to have reporting skills and } \\
\text { knowledge in cloud accounting. They will then be able to quickly hit the ground running when } \\
\text { interacting with new software. }\end{array}$ \\
\hline $\begin{array}{l}\text { P02 } \\
\text { Investment } \\
\text { Holding, } \\
\text { Integrated } \\
\text { Report } \\
\text { Preparers III } \\
1-5 \text { years }\end{array}$ & $\begin{array}{l}\text { Accounting and Finance people need to become more versatile on using technology for reporting. } \\
\text { An e.g. is a software called Numbers which helps financial information to be reported easily with } \\
\text { very little risk of human errors. }\end{array}$ \\
\hline $\begin{array}{l}\text { S02 } \\
\text { Professional } \\
\text { Services, } \\
\text { Other } \\
\text { stakeholders } \\
1-5 \text { vears }\end{array}$ & $\begin{array}{l}\text { Employees need to be trained or at least be updated with latest best practices. They should be well } \\
\text { acquainted to digital tools. Just academically or theoretically good, is not enough in this era where } \\
\text { every operation is computerized. }\end{array}$ \\
\hline
\end{tabular}

The ICT skills that are relevant to the profession are not restricted to just tools and software usage but also extended to reporting technologies. For instance, with the emergence of ICT, big data has become increasingly important for the profession, even as new types of data has become accessible. This has been stated by respondent P04 as follows:

\begin{tabular}{ll}
\hline P02 & They should be aware of how to deal with information which is generated by information systems. \\
Financial & There is a big flow of information due to the emergence of ICT (big data). It is for accountants to \\
Services, & identify how relevant and accurate these information are for decision making purposes, If they have \\
Integrated & no knowledge of ICT, they will not be able to assist in any decision making process nor any strategic \\
Report & planning. \\
Preparers III & \\
$1-5$ years &
\end{tabular}

This has influenced how business is conducted and how financial statements are prepared and audited. There are two noticeable trends of big data in managerial accounting, financial accounting, and financial reporting practices. Therefore, if the employees are not ICT literate, they will struggle to provide useful information to enhance 
transparency and stakeholder decision making as the dynamic, real-time, global economy evolves (Warren, Moffitt \& Byrnes, 2015). At the same time, if the employees do not already possess this skill and knowledge, it becomes a burden on the company to train the employees as they are recruited. Moreover this would be an additional cost.

\begin{tabular}{ll}
\hline B02 & The employee should have better training in the ICT and have good knowledge on IR. This will \\
Professional & prove very costly for companies as the burden will lie on the Head of Finance. Therefore, if tertiary \\
institutions could take this responsibility to provide the appropriate skills to the graduates. This will \\
$\begin{array}{l}\text { Integrated } \\
\text { Report }\end{array}$ & $\begin{array}{l}\text { allow new accounting professionals to integrate and adapt to any systems with the minimum of } \\
\text { hindrances. }\end{array}$ \\
$\begin{array}{l}\text { 1-5 years } \\
\text { hrepars I }\end{array}$ &
\end{tabular}

4.5.1.2 Reporting Knowledge \& Skills

Although the majority of respondents have positively admitted that ICT plays a vital role in the accounting profession and it helps greatly in reporting and data manipulation in information systems, it has been further questioned by some respondents. They do agree with the benefits which ICT brings about to the profession. However, they believe that more than ICT, there is a real need for reporting knowledge and skills regardless of ICT progress. 19 respondents stressed a lot on reporting knowledge and skills, that is, even if information are generated by systems, accountants should use their reporting skills to interpret the information quantitatively and qualitatively.

\begin{tabular}{|c|c|}
\hline $\begin{array}{l}\text { B04 } \\
\text { Consumer Goods, } \\
\text { Integrated Report } \\
\text { Preparer I } \\
1-5 \text { years }\end{array}$ & $\begin{array}{l}\text { Well knowledgeable of how and when to use Accounting standards and how to manipulat } \\
\text { different accounting systems. I also believe that accountants should have knowledge in regulatory } \\
\text { requirements, risk managements and technological skills. At present, accountants lack knowledg } \\
\text { in transformation of new disclosure regulations, new forms of disclosures, and awareness of the } \\
\text { interconnectedness of financial and non-financial reporting. Professional accountants will need } \\
\text { the skills to provide more all-inclusive corporate reporting, which tells less about the number } \\
\text { and more about the narrative of the organization. }\end{array}$ \\
\hline $\begin{array}{l}\text { P20 } \\
\text { Transportation, } \\
\text { travel \& tourism, } \\
\text { Integrated Report } \\
\text { Preparer III }\end{array}$ & $\begin{array}{l}\text { The employee should be knowledgeable of the reporting of both quantitative and qualitative } \\
\text { information since this is a new concept which is taking the lead now. IR is normally included in } \\
\text { the Annual Report and reported once a year. Therefore, even if information is available in rea } \\
\text { time through technology, accountants should know how to manipulate the information fo } \\
\text { different stakeholders }\end{array}$ \\
\hline $6-10$ years & \\
\hline
\end{tabular}

It can be deduced that the respondents have not ignored the importance of ICT in the profession. They have only highlighted the need for reporting skills.

\subsubsection{Generic Skills}

The findings revealed a minority of respondents (14 out of 70) believe that that more than ICT, it is the mindset of accountants which needs to shift to be able to cope with the concept of IR. This implies that there is a demand for employees with generic skills for an accounting career success. Generic skills are high-order, transferable skills that are common to most complex endeavors. They include skills such as communicating, problem-solving, patience, flexibility, persistence, resilience, courage and creativity that apply across all specific fields. They help to organize, adapt, and strategically apply technical skills in new situations and circumstances. They are important today because work and life are in flux. Both are getting more complex. Both require flexibility, initiative, creativity, emotional mastery and the ability to take on many different tasks. Consistent with prior studies, this group of respondents prioritized generic skills for career success above ICT and reporting skills. This has been backed by the following quotes:

\begin{tabular}{|c|c|}
\hline $\begin{array}{l}\text { A08 } \\
\text { Manufacturing, } \\
\text { Integrated } \\
\text { Report Preparer } \\
\text { III, }\end{array}$ & $\begin{array}{l}\text { ICT is an emerging theme. However, IR does not rely on ICT, but is mainly a mindset shift to } \\
\text { provide greater transparency and better governance. IR requires thinking, willingness and courage, } \\
\text { over and above what any IT systems can provide. }\end{array}$ \\
\hline $6-10$ years & \\
\hline
\end{tabular}


P01

Financial

Services,

Auditor

6-10 years
Good analytical skills and ability to think outside the box/ critical thinking. Most importantly, their determination and motivation to learn and grow as professionals. We look for good team players who should be dynamic, proactive and should possess efficient planning skills.

\section{Conclusion}

The findings exhibit that most of the respondents had the knowledge of IR, although it is a fairly new concept in Mauritius. Further, respondents were asked if their companies have adopted the concept and only a minority mentioned that they are considering to adopt it while the majority have already implemented and they are using it as a new means of reporting. Most importantly, they agreed that IR has several positive outcomes and more stress should be placed on gaining knowledge and skills to prepare the integrated reports. Moreover, to be able to effectively use IR, they found it relevant to have adequate skills to use reporting technologies. Among the 70 companies that participated in the survey, most of them (56\%) have recently adopted IR. The adoption of IR is bringing many benefits to organisations and stakeholders and the benefits outweigh the few challenges it poses. There is a high demand for accountants to have relevant skills and knowledge of this new concept, especially with the emergence of ICT which has brought about many changes to the profession. Therefore, to meet the requirements of the profession, there is an urge for HEIs in Mauritius to follow suit.

Future studies in the context of Mauritius could include a study to identify and to evaluate the ICT topics and techniques which are currently being taught in accounting faculties in Mauritius and whether they are relevant to the IR concept. Also, it could include an evaluation of whether HEIs possess the appropriate conditions to meet the challenges of emerging ICTs in Accounting Education. Moreover, a study to examine the attitude of accounting academics and students towards the use of relevant ICT in the teaching and learning process.

\section{References}

Adhariani, D., \& de Villiers, C. (2018). Integrated reporting: perspectives of corporate report preparers and other stakeholders. Sustainability Accounting, Management and Policy Journal, SAMPJ-02-2018-0043. https://doi.org/10.1108/SAMPJ-02-2018-0043

Ahmed Haji, A., \& Anifowose, M. (2016). The trend of integrated reporting practice in South Africa: Ceremonial or substantive? Sustainability Accounting, Management and Policy Journal, 7(2), 190-224. doi:http://dx.doi.org.dbgw.lis.curtin.edu.au/10.1108/SAMPJ-11-2015-0106

Ahmed Haji, A., \& Anifowose, M. (2017). Initial trends in corporate disclosures following the introduction of integrated reporting practice in south africa.Journal of Intellectual Capital, 18(2), 373-399. http://dx.doi.org.dbgw.lis.curtin.edu.au/10.1108/JIC-01-2016-0020

Ahmed Haji, A., \& Hossain, D. M. (2016). Exploring the implications of integrated reporting on organisational reporting practice. Qualitative Research in Accounting and Management, 13(4), 415-444. https://doi.org/10.1108/QRAM-07-2015-0065

Atkins, J. F., Solomon, A., Norton, S., \& Joseph, N. L. (2015). The emergence of integrated private reporting. Meditari Accountancy Research, 23(1), 28-61. Retrieved from https://search-proquest-com.dbgw.lis.curtin.edu.au/docview/1668188838?accountid=10382

Atkins, J., \& Maroun, W. (2015). Integrated reporting in South Africa in 2012.Meditari Accountancy Research, 23(2), 197-221. Retrieved from https://search-proquest-com.dbgw.lis.curtin.edu.au/docview/1692034938?accountid=10382

Avcı, Ö., Ring, E. \& Mitchell, L. (2015). Stakeholders in U.S. higher education: An analysis through two theories of stakeholders. Bilgi Ekonomisi ve Yönetimi Dergisi, 10(2), 45-54. Available at: http://dergipark.ulakbim.gov.tr/beyder/article/view/5000166649.

Becker, G. (2009). Human Capital. Chicago: The University of Chicago Press.

Benneworth, P., \& Jongbloed, B. (2010). Who matters to universities? A stakeholder perspective on humanities, arts and social sciences valorisation. Higher Education, 59(5), 567-588. https://doi.org/10.1007/s10734-009-9265-2

Bhasin, D. (2017). Integrated Reporting at the Crossroads: Will it Become Trendsetter Model for the Corporate Reporting. International Journal of Management Sciences and Business Research, 6(2). Available at: http://www.ijmsbr.com/Volume\%206\%20Issue\%202\%20Paper\%204.pdf 
Chapleo, C. \& Christopher, S. (2010). Stakeholder analysis in higher education: A case study of the University of Portsmouth. Perspectives: Policy and Practice in Higher Education, 14(1), 12-20. https://doi.org/10.1080/13603100903458034

Deegan, C., \& Rankin, M. (1997). The materiality of environmental information to users of annual reports. Accounting, Auditing \& Accountability Journal, 10(4), 562-583. https://doi.org/10.1108/09513579710367485.

Dellaportas, S., Gibson, K., Alagiah, R., Hutchinson, M., Leung, P. \& Van Homrigh, D. (2005). Ethics, governance and accountability: A professional perspective, John Wiley \& Sons, Milton, Qld.

du Toit, E., van Zyl, R. and Schütte, G. (2017). Integrated reporting by South African companies: a case study. Meditari Accountancy Research, 25(4), 654-674. https://doi.org/10.1108/medar-03-2016-0052

Dumay, J., Bernardi, C., Guthrie, J., \& Demartini, P. (2016). Integrated reporting: A structured literature review. Accounting Forum, 40(3), 166-185. https://doi.org/10.1016/j.accfor.2016.06.001

Eccles, R. (2010). One Report: Are You Ready? Don't let the skeptics stop you from integrated reporting. IESE Insight, (5), 6-6. https://doi.org/10.15581/002.opi-892

Eccles, R. \& Saltzman, D. (2011). Achieving sustainability through integrated reporting. Stanford Social Innovation Review, 9(3), 56-61.

Etikan, I. (2016). Comparison of Convenience Sampling and Purposive Sampling. American Journal of Theoretical and Applied Statistics, 5(1), 1. https://doi.org/10.11648/j.ajtas.20160501.11

EY (2017). Why Richard Howitt is on a mission to improve corporate reporting. Retrieved from https://www.ey.com/en_gl/assurance/why-richard-howitt-is-on-a-mission-to-improve-corporate-reporting

Freeman, R (1984). Strategic Management: A Stakeholder Approach, Pitman, Marshall, MA.

García-Sánchez, I., Rodríguez-Ariza, L. \& Frías-Aceituno, J. (2013). The cultural system and integrated reporting. International Business Review, 22(5), 828-838. https://doi.org/10.1016/j.ibusrev.2013.01.007

GRI. (2018). Integrated Reporting. Retrieved from https://www.globalreporting.org/information/current-priorities/integrated-reporting/Pages/default.aspx

Haller, A., \& Chris, v. S. (2014). The value added statement - an appropriate instrument for integrated reporting. Accounting, Auditing \& Accountability Journal, 27(7), 1190-1216. http://dx.doi.org.dbgw.lis.curtin.edu.au/10.1108/AAAJ-04-2013-1307

Hopwood, A., Unerman, J., \& Fries, J. (Eds.). (2010). Accounting for sustainability: practical insights. Retrieved from https://ebookcentral.proquest.com

Hsiao, P. and Kelly, M. (2018). Investment considerations and impressions of integrated reporting. Sustainability Accounting, Management and Policy Journal, 9(1), 2-28. https://doi.org/10.1108/sampj-10-2016-0072

IIRC (2013). The international Integrated Reporting framework | Integrated Reporting. Retrieved from http://integratedreporting.org/wp-content/uploads/2015/03/13-12-08-THE-INTERNATIONAL-IR-FRAMEWO RK-2-1.pdf

IIRC. (2015). IIRC Integrated Report 2015 | Integrated Reporting. Retrieved from http://integratedreporting.org/news/iirc-integrated-report-2015/

IR Technology Initiative. (2016). Technology for Integrated Reporting: A CFO guide for driving multi capital thinking. Retrieved

from http://integratedreporting.org/wp-content/uploads/2016/10/Technology-for-Integrated-Reporting_CFOguide.pdf

ISCA-NUS. (2014). Integrated reporting survey 2014 [EBook]. Institute of Singapore Chartered Accountants (ISCA). Retrieved from https://isca.org.sg/media/775709/isca-nus-integrated-reporting-survey-2014.pdf

Islam, R. and Islam, M.R. (2018). Insights the Practice of Integrated Reporting: A Study on MNCs in Bangladesh on the Degree of Adherence to the Reporting Framework. Open Journal of Business and Management, 6, 733-748. https://doi.org/10.4236/ojbm.2018.63056

Kaiser, H. F. (1974). An index of factorial simplicity. Psychometrika, 39, 31-36.

Lehmann, D. (1975). Validity and Goodness of Fit in Data Analysis. Retrieved from http://acrwebsite.org/volumes/5796/volumes/v02/NA-02

Lipunga, A. (2015). Corporate Social Responsibility Reporting through the Lens of ISO 26000: A Case of Malawian Quoted Companies. International Business Research, 8(2). http://dx.doi.org/10.5539/ibr.v8n2p28 
Lodhia, S. (2015). Exploring the transition to integrated reporting through a practice lens: An Australian customer owned bank perspective. Journal of Business Ethics, 129(3), 585-598. http://dx.doi.org.dbgw.lis.curtin.edu.au/10.1007/s10551-014-2194-8

McNally, M., Cerbone, D., \& Maroun, W. (2017). Exploring the challenges of preparing an integrated report. Meditari Accountancy Research, 25(4), 481-504. Retrieved from https://search-proquest-com.dbgw.lis.curtin.edu.au/docview/1948367329?accountid=10382

MIA-ACCA. (2016). Integrated Reporting Survey [EBook]. Malaysian Institute of Accountants (MIA). Retrieved from http://integratedreporting.org/wp-content/uploads/2016/09/MIA-ACCA-IR-survey-report_2016.pdf.pdf

Nicolescu, L. \& Paun, C. (2009). Relating Higher Education with the Labour Market: Graduates' expectations and employers' requirements, Tertiary Education

and Management, 15(1), 17-33. https://doi.org/10.1080/13583880802700024

Nylander, J. (2015). Why 'Integrated Reporting' Attracts Investors [Blog]. Retrieved from https://www.forbes.com/sites/jnylander/2015/11/11/why-integrated-reporting-attracts-investors/\#26ca523c57e7

Owen, G. (2013). Integrated Reporting: A Review of Developments and their Implications for the Accounting Curriculum. Accounting Education, 22(4), 340-356. https://doi.org/10.1080/09639284.2013.817798

Perego, P., Kennedy, S., \& Whiteman, G. (2016). A Lot of Icing but Little Cake? Taking Integrated Reporting Forward. SSRN Electronic Journal. https://doi.org/10.2139/ssrn.2744822

Petrova, M. (2015). The Art of Business Strategy. Is Integrated Reporting a continuation of strategy by other means? [Blog]. Retrieved from http://www.kksadvisors.com/blog/2016/9/12/the-art-of-business-strategy-is-integrated-reportinga-continuationof-strategy-by-other-means

Reimsbach, D., Hahn, R., \& Gürtürk, A. (2017). Integrated Reporting and Assurance of Sustainability Information: An Experimental Study on Professional Investors' Information Processing. European Accounting Review, 27(3), 559-581. https://doi.org/10.1080/09638180.2016.1273787

Rensburg, R., \& Botha, E. (2014). Is Integrated Reporting the silver bullet of financial communication? A stakeholder perspective from South Africa. Public Relations Review, 40(2), 144-152. https://doi.org/10.1016/j.pubrev.2013.11.016

Robert Half. (2016). 2017 Salary \& hiring preview. Retrieved from https://www.roberthalf.com/sites/default/files/Media_Root/images/rh-pdfs/robert_half.2017_salary_preview.8.2 2.16.pdf

Robertson, F. A., \& Samy, M. (2015). Factors affecting the diffusion of integrated reporting - a UK FTSE 100 perspective. Sustainability Accounting, Management and Policy Journal, 6(2), 190-223. http://dx.doi.org.dbgw.lis.curtin.edu.au/10.1108/SAMPJ-07-2014-0044

Roman, A. (2017). King III Report: How South Africa Revolutionised Corporate Governance. Azeus Convene. Available at: https://www.azeusconvene.com/south-africa-revolutionize-corporate-governance

Schurman, S., \& Soares, L. (2010). Connecting the dots: Creating a postsecondary education system for the 21 st-century workforce. In D. Finegold, M. Gatta, H. Salzman, \& S. Schurman (Eds.), transforming the U.S. workforce development system: Lessons from research and practice, 125-151). Champaign, IL: Labor and Employment Relations Association.

SEM. (2018). Stock Exchange of Mauritius (SEM) - Listed Companies | AFRICAN MARKETS. Retrieved from https://www.african-markets.com/en/stock-markets/sem/listed-companies

Setia, N., Abhayawansa, S., Joshi, M., \& Huynh, A. V. (2015). Integrated reporting in South Africa: Some initial evidence. Sustainability Accounting, Management and Policy Journal, 6(3), 397-424. http://dx.doi.org.dbgw.lis.curtin.edu.au/10.1108/SAMPJ-03-2014-0018

Steyn, M. (2014). Organisational benefits and implementation challenges of mandatory integrated reporting. Sustainability Accounting, Management and Policy Journal, 5(4), 476-503. Retrieved from https://search-proquest-com.dbgw.lis.curtin.edu.au/docview/1633971308?accountid=10382

Warren, J.D., Moffitt, K., \& Byrnes, P. (2015). How Big Data Will Change Accounting. Accounting Horizons, 29(2), 397-407. https://doi.org/10.2308/acch-51069 